\title{
Streptococcus infantarius
}

National Cancer Institute

\section{Source}

National Cancer Institute. Streptococcus infantarius. NCI Thesaurus. Code C86793.

A species of facultatively anaerobic, Gram positive, cocci shaped bacteria in the phylum

Firmicutes. This species is positive for esculin hydrolysis, alpha galactosidase and

Lancefield group D and negative for catalase, arginine deaminase, growth in $6.5 \% \mathrm{NaCl}$,

pyrrolidonylarylamidase and urease. It can ferment melibiose, lactose and sucrose but

not mannitol, sorbitol, inulin or trehalose. S infantarius has been isolated from infants and

is a human pathogen that can cause hepatobiliary bacteremia. 